\title{
DISSOLUTION KINETIC OF MELOXICAM FROM HYDROPHILIC MATRIX-TYPE FILMS FOR TRANSDERMAL THERAPY
}

\author{
PAULA ANTONOAEA ${ }^{1}$, EMÖKE MARGIT RÉDAI ${ }^{1 *}$, MAGDALENA BÎRSAN ${ }^{2}$, ANAMARIA \\ TĂTARU ${ }^{1}$, NICOLETA TODORAN ${ }^{1}$, ROBERT ALEXANDRU VLAD ${ }^{1}$, DANIELA-LUCIA \\ MUNTEAN $^{3}$, ADRIANA CIURBA $^{1}$ \\ 1 "George Emil Palade" University of Medicine, Pharmacy, Science and Technology of Târgu Mureș, Faculty of Pharmacy, \\ Department of Pharmaceutical Technology and Cosmetology, 38 Gheorghe Marinescu Street, 540142, Târgu Mureș, Romania \\ 2 "Grigore T. Popa" University of Medicine and Pharmacy of Iași, Faculty of Pharmacy, Department of Pharmaceutical \\ Technology, 16 Universității Street, 700115, Iași, Romania \\ 3 “George Emil Palade” University of Medicine, Pharmacy, Science and Technology of Târgu Mureș, Faculty of Pharmacy, \\ Department of Analytical Chemistry and Drug Analysis, 38 Gheorghe Marinescu Street, 540142, Târgu Mureș, Romania
}

*corresponding author: emoke.redai@umfst.ro

Manuscript received: June 2020

\begin{abstract}
Taking into consideration the fact that the transdermal administration of the active pharmaceutical ingredients can represent a therapeutic approach that increases the patient's compliance, this study aims to evaluate the release of meloxicam (MX), a potent non-steroidal anti-inflammatory drug, incorporated in hydrophilic polymer-based matrices for transdermal therapeutic systems was studied. Three different formulations were realized by solvent casting method containing two types of hydroxypropyl methylcellulose (HPMC $\mathrm{E}_{5}$ with low viscosity and $\mathrm{HPMC}_{15000}$ with high viscosity) whose concentration was also varied. The drug release test was performed by Franz diffusion cell and the dissolution curves were analysed from a kinetical point of view by model dependent and model independent methods. Linearization by simple regression allowed the flux calculations of values that varied between 0.183 and $32.270 \mu \mathrm{g} /\left(\mathrm{cm}^{2} \mathrm{~h}\right)$. Based on the results obtained with the mathematical analysis, we can conclude that the MX release is influenced by the $\mathrm{pH}$ of the dissolution media and by the type and concentration of the matrix forming agent. Discrimination of model dependent mathematical models was done by the Akaike index with values between 49 and -62 . The kinetic analysis of the MX releasing curves from the proposed formulations showed that Korsmeyer-Peppas was more suitable for the release characterisation of the active pharmaceutical ingredient from the transdermal therapeutic systems analysed.
\end{abstract}

\section{Rezumat}

Luând în considerare faptul că administrarea transdermică a substanțelor medicamentoase poate reprezenta o abordare terapeutică care să crească complianța pacienților, prezentul studiu își propune să studieze cedarea transdermică a meloxicamului (MX) din filme polimerice. Prin metoda evaporării solventului, s-au realizat trei formulări de sisteme terapeutice transdermice în care s-a variat sortimentul de hidroxipropil-metilceluloză utilizat (HPMCE5 de vâscozitate joasă, respectiv HPMC15000 de vâscozitate crescută), dar și concentrația acestuia. Pentru studiile de cedare a MX s-a utilizat celula de difuzie Franz, iar curbele de cedare au fost analizate din punct de vedere cinetic prin metode model dependente și model independente. Liniarizarea prin regresie simplă a permis calcularea fluxului prin membrane, valorile obținute variind între 0,183 și 32,270 $\mu \mathrm{g} /\left(\mathrm{cm}^{2} \mathrm{~h}\right)$. Pe baza rezultatelor analizei matematice putem concluziona faptul că eliberarea substanței active este influențată de pH-ul mediului de dizolvare, dar şi de tipul și concentrația polimerului formator de matriţă. Indicele Akaike a fost parametrul discriminator pentru selectarea modelului matematic potrivit cu valori între 49 și -62 . Analiza cinetică a curbelor de cedare a MX din formulările propuse în studiu ne-a arătat că modelul matematic Korsmeyer-Peppas a fost mai potrivit pentru descrierea eliberării substanței active din sistemele transdermice analizate.

Keywords: meloxicam, transdermal system, hydrophilic matrix, dissolution, kinetic analysis

\section{Introduction}

Meloxicam is a selective nonsteroidal anti-inflammatory drug, acting preferentially on COX-2 enzyme $[3,5,13$, 17]. Taking into consideration patient compliance in long term treatment, transdermal delivery of meloxicam is a therapeutic possibility for the permeation of active ingredient through the skin, avoiding gastrointestinal side effects $[2,20]$.
Transdermal drug delivery of meloxicam had been studied for various pharmaceutical forms. Oil in water microemulsion has been formulated and studied for an enhanced skin permeation rate [24]. Nanoemulsion based gels for transdermal therapy were developed to ensure sustained and controlled release $[16,18]$. Meloxicam loaded cationic transfersomes provided enhanced permeation compared to liposomes [12]. Polyvinyl alcohol based electrospun nanofiber mats 
were compered to PVA cast films and proved a higher permeation flux [17]. Microsponges are also studied for transdermal drug delivery, and the drug release was best modelled by first order release kinetic. Meloxicam release from the sponges is controlled by diffusion and polymer relaxation [20]. Transdermal patches using hydroxypropyl methylcellulose, ethyl cellulose, polyvinyl pyrrolidone and plasticizers were prepared by solvent casting technique and studied for release kinetic. Liberation of meloxicam followed a zero-order kinetics [23].

Mathematical modelling is a powerful tool in clarifying the release kinetic of an active ingredient from a hydrophilic matrix intended for controlled release for a long time period $[8,10]$. In the case of transdermal formulations the drug release mechanism may be diffusion (Fickian) through the polymeric matrix. Higuchi and Korsmeyer-Peppas models are simple and useful models used to describe the release from matrix transdermal therapeutic systems (TTS) [7, 8]. An appropriate mathematical model allows a reliable risk assessment before in vivo evaluations. Validated mathematical models can be considered as economic alternatives for the assessment of skin permeation, and their use has been recommended before in vitro and in vivo experiments are conducted [15].

In this experimental study we aimed to prepare by solvent casting method three polymeric films with meloxicam and to characterize from a kinetic point of view the release of the active pharmaceutical ingredient from the proposed matrices. Two types of polymers were used: hydroxipropyl-cellulose $e_{\mathrm{E} 5}$ (HPMC $\left.\mathrm{E}_{\mathrm{E}}\right)$ and hydroxipropyl-cellulose ${ }_{15000}\left(\mathrm{HPMC}_{15000}\right)$ that differ in the number of methoxide and hydroxypropyl groups in their structure, and also by their viscosity, a $2 \%$ polymer solution presenting a viscosity of de $4-6 \mathrm{mPa} \cdot \mathrm{s}$ and $15000 \mathrm{mPa} \cdot \mathrm{s}$, respectively.

\section{Materials and Methods}

\section{Materials}

Meloxicam (Techno Drugs \& Intermediates Ltd. Mumbai, India), hydroxypropyl methylcellulose (HPMC $\mathrm{E}_{\mathrm{E}}$, Ethocel E5) with a viscosity of $5 \mathrm{mPa} \cdot \mathrm{s}$, (Dow Chemical Co., Midland, USA) and HPMC 15000 (Metolose 90SH) with a viscosity of $15000 \mathrm{mPa} \cdot \mathrm{s}$, (Shin-Etsu Chemical Co., Ltd. Tokyo, Japan), propylene glycol (PG) (Scharlau Chemie, Barcelona, Spain), Tween 20 (Tw20) (Sigma Aldrich Co., France), ethanol (Chemical Company, Romania), acetonitrile (Merk, Germany), methanol (Merk, Germany) as HPLC solvents with HPLC analytical grade; ultrapure water; potassium phosphate $\mathrm{KH}_{2} \mathrm{PO}_{4}$ (Merk, Germany) and phosphoric acid (Merk, Germany). Preparation of hydrophilic matrices

Three formulations have been prepared, using two types of hydrophilic polymers (Table I). The used solvent evaporation method was described previously [2], but briefly MX was added in ethanol and propylene glycol under continuous stirring. After that a mixture of Tween 20 and ultrapure water was added and stirring was continued for two hours to disperse the hydrophilic polymer. This dispersion was sonicated in an ultrasound bath for 30 minutes and casted into Petri dishes ( $9.8 \mathrm{~cm}$ diameter). The matrices were dried for $24 \mathrm{~h}$ at $40^{\circ} \mathrm{C}$.

Table I

The composition of polymeric matrices

\begin{tabular}{|l|c|c|c|}
\hline \multirow{2}{*}{ Composition } & \multicolumn{3}{|c|}{ Amount \% (w/w) } \\
\cline { 2 - 4 } & M1 & M2 & M3 \\
\hline MX & 0.5 & 0.5 & 0.5 \\
\hline HPMC 55 & 3.0 & 3.0 & 3.0 \\
\hline HPMC $_{15000}$ & - & 1.0 & 1.5 \\
\hline PG & 10.0 & 10.0 & 10.0 \\
\hline Tw$_{20}$ & 1.0 & 1.0 & 1.0 \\
\hline Ethanol & 30.0 & 30.0 & 30.0 \\
\hline Ultrapure water & q.s & q.s & q.s \\
\hline
\end{tabular}

Dissolution/in vitro permeation studies

The release of active substance was determined using Franz cells (Hanson Research, USA) in $14 \mathrm{~mL}$ phosphate buffer solution at $\mathrm{pH} 5.5$ and 7.4 , at $32 \pm 0.5^{\circ} \mathrm{C}$. The amount of MX was assayed by a chromatographic method described previously. A HPLC Agilent Tech. 1100 Series (USA) with quaternary pump, degasser, automatic injector, column thermostat, ultraviolet detector and software (Chemstation software); Waters Symmetry C8 column, 4.6 x 150 mm, $5 \mu \mathrm{m}$ was used. Chromatographic conditions for MX: mobile phase phosphate buffer $\left(\mathrm{KH}_{2} \mathrm{PO}_{4} 20 \mathrm{mM}, \mathrm{pH} 3.0\right)$ :acetonitrile $(60: 40 \mathrm{v} / \mathrm{v}) ; 1.0 \mathrm{~mL} / \mathrm{min}$ flow; detection at $362 \mathrm{~nm}$; column temperature was set at $35^{\circ} \mathrm{C}$; volume injected $5 \mu \mathrm{L}$ [1]. A synthetic membrane, MS (nylon, diameter $25 \mathrm{~mm}$, width $0.45 \mu \mathrm{m}$, Tekronoma) and pig ear skin, MP (diameter $25 \mathrm{~mm}$, width $<1 \mathrm{~mm}$ ) had been used as membranes. All tests were carried out in triplicate.

\section{Mathematical modelling of release profiles}

The dissolution curves had been analysed by DDSolver Add-In Program, Microsoft-Excel software by model dependent and model independent methods.

In case of model independent analysis similarity and difference factor were calculated using the wellknown formulas [8].

$$
f_{1}=\left\{\left[\sum_{t=1}^{n}\left|R_{t}-T_{t}\right|\right] /\left[\sum_{t=1}^{n} R_{t}\right]\right\} \cdot 100,
$$

where: $f_{l}$ express $\%$ of the differences calculated for each point of the two curves and it is the measurement of the relative error between two profiles.

$$
f_{2}=50 \cdot \log \left\{\left[1+(1 / n) \sum_{t=1}^{n}\left(R_{t}-T_{t}\right)^{2}\right]^{-0.5} \cdot 100\right. \text {, }
$$

where: $f_{2}$ express $\%$ of the similarity of the two curves. As reference a meloxicam containing hydrophilic matrix was used. Model dependent analysis was performed with 26 (Table II) different mathematical from the DDSolver add-in software [25]. As a first step the Akaike index ("Akaike Informational Criterion" - AIC), a "goodness of fit" indicator, and then the adjusted 
FARMACIA, 2021, Vol. 69, 1

determination coefficient $\left(\mathrm{R}^{2}\right.$ ajusted $)$ were calculated. The best fit model was selected by lowest Akaike value and $\mathrm{R}_{\text {ajusted }}^{2}$ closer to 1.0 value.

AIC may be calculated:

$$
A I C=2 K-2 \ln (\tau)
$$

where $\mathrm{K}$ is the number of model parameters and $\tau$ the maximum value of the likehood function of the model. Flux rate and latency time calculation was realised by graphic method after the linearization of release profiles in the steady state $[6,10,14,25]$ with GraphPad (version 7.05) and DDSolver software.

Table II

Different mathematical models for comparison of meloxicam release kinetic

\begin{tabular}{|c|c|c|c|}
\hline No. & Mathematical model & Equation & \\
\hline 1. & 0 order kinetic & $\mathrm{F}=\mathrm{k}_{0} * \mathrm{t}$ & \multirow{26}{*}{ 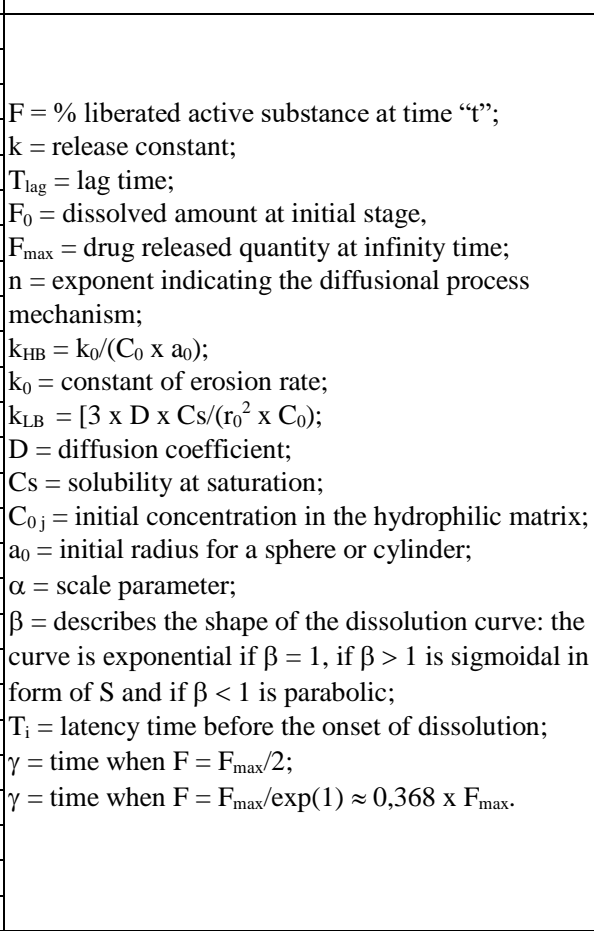 } \\
\hline 2. & 0 order kinetic with Tlag & $\mathrm{F}=\mathrm{k}_{0} *\left(\mathrm{t}-\mathrm{T}_{\mathrm{lag}}\right)$ & \\
\hline 3. & 0 order kinetic with $\mathrm{F}_{0}$ & $\mathrm{~F}=\mathrm{F}_{0}+\mathrm{k}_{0} * \mathrm{t}$ & \\
\hline 4. & First order kinetic & $\mathrm{F}=100 *[1-\operatorname{Exp}(-\mathrm{k} 1 * \mathrm{t})]$ & \\
\hline 5. & First order kinetic with Fmax & $\mathrm{F}=\mathrm{F}_{\max } *\left[1-\operatorname{Exp}\left(-\mathrm{k}_{1} * \mathrm{t}\right)\right]$ & \\
\hline 6. & First order kinetic with $T_{\text {lag }}$ and $F_{\max }$ & $\mathrm{F}=\mathrm{F}_{\max } *\left\{1-\operatorname{Exp}\left[-\mathrm{k}_{1} *\left(\mathrm{t}-\mathrm{T}_{\mathrm{lag}}\right)\right]\right\}$ & \\
\hline 7. & Higuchi & $\mathrm{F}=\mathrm{kH} * \mathrm{t}^{\wedge} 0.5$ & \\
\hline 8. & Higuchi with $\mathrm{T}_{\text {lag }}$ & $\mathrm{F}=\mathrm{k}_{\mathrm{H}} *\left(\mathrm{t}-\mathrm{Tl}_{\mathrm{ag}}\right)^{\wedge} 0.5$ & \\
\hline 9. & Higuchi with $\mathrm{F}_{0}$ & $\mathrm{~F}=\mathrm{F}_{0}+\mathrm{k}_{\mathrm{H}} * \mathrm{t}^{\wedge} 0.5$ & \\
\hline 10. & Korsmeyer-Peppas & $\mathrm{F}=\mathrm{k}_{\mathrm{KP}} * \mathrm{t}^{\wedge} \mathrm{n}$ & \\
\hline 11. & Korsmeyer-Peppas with $\mathrm{T}_{\text {lag }}$ & $\mathrm{F}=\mathrm{k}_{\mathrm{KP}} *\left(\mathrm{t}-\mathrm{T}_{\text {lag }}\right)^{\wedge} \mathrm{n}$ & \\
\hline 12. & Korsmeyer-Peppas with $\mathrm{F}_{0}$ & $\mathrm{~F}=\mathrm{F}_{0}+\mathrm{k}_{\mathrm{KP}} * \mathrm{t}^{\wedge} \mathrm{n}$ & \\
\hline 13. & Hixon-Crowel & $\mathrm{F}=100 *\left[1-(1-\mathrm{kHC} * \mathrm{t})^{\wedge} 3\right]$ & \\
\hline 14. & Hixon-Crowel with $\mathrm{T}_{\text {lag }}$ & $\mathrm{F}=100 *\left\{1-\left[1-\mathrm{k}_{\mathrm{HC}} *\left(\mathrm{t}-\mathrm{T}_{\mathrm{lag}}\right)\right]^{\wedge} 3\right\}$ & \\
\hline 15. & Hopfenberg & $\mathrm{F}=100 *\left[1-\left(1-\mathrm{k}_{\mathrm{HC}} * \mathrm{t}\right)^{\wedge} 3\right]$ & \\
\hline 16. & Hopfenberg with $\mathrm{T}_{\text {lag }}$ & $\mathrm{F}=100 *\left\{1-\left[1-\mathrm{k}_{\mathrm{HB}} *\left(\mathrm{t}-\mathrm{T}_{\mathrm{lag}}\right)\right]^{\wedge} \mathrm{n}\right\}$ & \\
\hline 17. & Peppas-Sahlin-1 & $\mathrm{F}=\mathrm{k} 1 * \mathrm{t}^{\wedge} \mathrm{m}+\mathrm{k} 2 * \mathrm{t}^{\wedge}(2 * \mathrm{~m})$ & \\
\hline 18. & Peppas-Sahlin-1 with $\mathrm{T}_{\text {lag }}$ & $\mathrm{F}=\mathrm{k}_{1} *\left(\mathrm{t}-\mathrm{T}_{\mathrm{lag}}\right)^{\wedge} \mathrm{m}+\mathrm{k}_{2} *\left(\mathrm{t}-\mathrm{T}_{\mathrm{lag}}\right)^{\wedge}(2 * \mathrm{~m})$ & \\
\hline 19. & Peppas-Sahlin-2 & $\mathrm{F}=\mathrm{k}_{1} * \mathrm{t}^{\wedge} 0.5+\mathrm{k}_{2} * \mathrm{t}$ & \\
\hline 20. & Peppas-Sahlin-2 with $\mathrm{T}_{\text {lag }}$ & $\mathrm{F}=\mathrm{k}_{1} *\left(\mathrm{t}-\mathrm{T}_{\mathrm{lag}}\right)^{\wedge} 0.5+\mathrm{k}_{2} *\left(\mathrm{t}-\mathrm{T}_{\mathrm{lag}}\right)$ & \\
\hline 21. & Quadratic & $\mathrm{F}=100 *\left(\mathrm{k}_{1} * \mathrm{t}^{\wedge} 2+\mathrm{k}_{2} * \mathrm{t}\right)$ & \\
\hline 22. & Quadratic with $\mathrm{T}_{\mathrm{lag}}$ & $\mathrm{F}=\mathrm{k}_{1} *\left(\mathrm{t}-\mathrm{T}_{\mathrm{lag}}\right)^{\wedge} 0.5+\mathrm{k}_{2} *\left(\mathrm{t}-\mathrm{T}_{\mathrm{lag}}\right)$ & \\
\hline 23. & Weibull-1 & $\mathrm{F}=100 *\left\{1-\operatorname{Exp}\left[-\left((\mathrm{t}-\mathrm{Ti})^{\wedge} \beta\right) / \alpha\right]\right\}$ & \\
\hline 24. & Weibull-2 & $\mathrm{F}=100 *\left\{1-\operatorname{Exp}\left[-\left(\mathrm{t}^{\wedge} \beta\right) / \alpha\right]\right\}$ & \\
\hline 25. & Weibull-3 & $\mathrm{F}=\mathrm{F}_{\max } *\left\{1-\operatorname{Exp}\left[-\left(\mathrm{t}^{\wedge} \beta\right) / \alpha\right]\right\}$ & \\
\hline 26. & Weibull-4 & $\mathrm{F}=\mathrm{F}_{\max } *\left\{1-\operatorname{Exp}\left[-\left((\mathrm{t}-\mathrm{Ti})^{\wedge} \beta\right) / \alpha\right]\right\}$ & \\
\hline
\end{tabular}
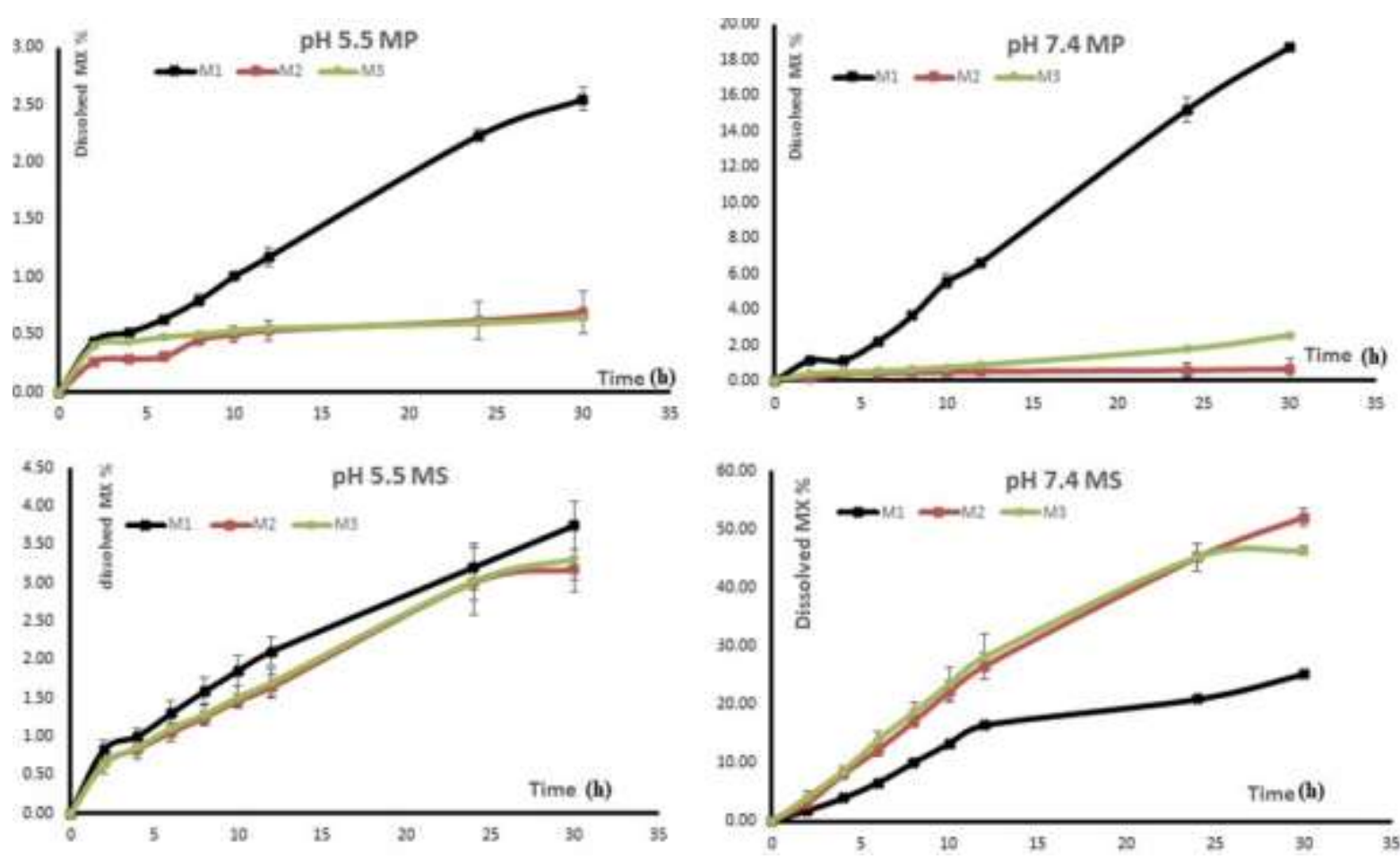

Figure 1.

Dissolution curves of meloxicam 
FARMACIA, 2021, Vol. 69, 1

\section{Results and Discussion}

Figure 1 presents the dissolution curves of the three formulations at two different $\mathrm{pH}$ using synthetic membrane and porcine ear skin, as biological membrane. The dissolved amount of MX after 30 hours at a $\mathrm{pH}$ 5.5 through a synthetic membrane varies between 3.18 and $3.75 \%$. In the same conditions while using a pork membrane conducted to a released amount of MX in the range of $0.65-2.55 \%$. At the $\mathrm{pH}$ of 7.4 using a MS the quantity release was between $25.15-52.1 \%$ whilst in the case of MP the range was between $0.66-18.71 \%$.

Accepted difference factor $\left(\mathrm{f}_{1}\right)$ (Table III) values are in the value range of 0 to 15 , and for similarity factor $\left(f_{2}\right)$ among 50 - 100, respectively.

Table III

$f_{1}$ and $f_{2}$ values for the proposed formulations

\begin{tabular}{|c|c|c|c|c|c|c|c|c|c|}
\hline Membrane & \multicolumn{6}{|c|}{ MS } & \multirow{2}{*}{\multicolumn{3}{|c|}{$\begin{array}{c}\text { MP } \\
5.5\end{array}$}} \\
\hline $\mathrm{pH}$ & & 5.5 & & & 7.4 & & & & \\
\hline Formula & M1 & M2 & M3 & M1 & M2 & M3 & M1 & M2 & M3 \\
\hline$f_{1}$ & 113.63 & 11.42 & 5.22 & 18.31 & 93.24 & 85.43 & 3.43 & 15.00 & 12.77 \\
\hline$f_{2}$ & 93.96 & 99.87 & 99.99 & 86.88 & 51.12 & 52.92 & 54.8 & 54.18 & 54.12 \\
\hline
\end{tabular}

Table IV

Parameters of representative models

\begin{tabular}{|c|c|c|c|c|c|c|c|c|c|c|c|c|c|}
\hline $\mathbf{M}$ & \multicolumn{7}{|c|}{ MS } & \multicolumn{6}{|c|}{ MP } \\
\hline $\mathrm{pH}$ & \multicolumn{4}{|c|}{ pH 5.5} & \multicolumn{3}{|c|}{$\mathrm{pH} 7.4$} & \multicolumn{3}{|c|}{ pH 5.5} & \multicolumn{3}{|c|}{$\mathrm{pH} 7.4$} \\
\hline No. & $\mathbf{P}$ & M1 & M2 & M3 & M1 & M2 & M3 & M1 & M2 & M3 & M1 & M2 & M3 \\
\hline \multirow{2}{*}{10.} & kKP & 0.44 & 0.31 & 0.32 & 2.18 & 2.90 & 4.00 & 0.15 & 0.19 & 0.35 & 0.33 & 0.22 & 0.09 \\
\hline & n & 0.63 & 0.69 & 0.70 & 0.73 & 0.86 & 0.74 & 0.83 & 0.38 & 0.18 & 1.19 & 0.34 & 0.98 \\
\hline \multirow{3}{*}{11.} & kKP & 0.44 & 0.31 & 0.32 & 3.51 & 4.49 & 6.14 & 0.14 & 0.20 & 0.35 & 0.46 & 0.34 & 0.01 \\
\hline & n & 0.63 & 0.69 & 0.70 & 0.59 & 0.74 & 0.62 & 0.86 & 0.37 & 0.18 & 1.11 & 0.19 & 1.55 \\
\hline & Tlag & 0.00 & -0.02 & -0.01 & 1.81 & 1.54 & 1.64 & -0.44 & 0.33 & 0.00 & 0.99 & 1.99 & -7.33 \\
\hline \multirow{3}{*}{12.} & kKP & 0.44 & 0.31 & 0.32 & 2.18 & 2.90 & 4.00 & 0.15 & 0.19 & 0.35 & 0.33 & 0.22 & 0.09 \\
\hline & n & 0.63 & 0.69 & 0.70 & 0.73 & 0.86 & 0.74 & 0.83 & 0.38 & 0.18 & 1.19 & 0.34 & 0.98 \\
\hline & Fo & 0.00 & 0.00 & 0.00 & 0.00 & 0.00 & 0.00 & 0.00 & 0.00 & 0.00 & 0.00 & 0.00 & 0.00 \\
\hline \multirow{3}{*}{17.} & $\mathbf{k 1}$ & 0.40 & 0.28 & 0.30 & -37.54 & -16.65 & -38.86 & 0.16 & 0.17 & - & -0.75 & 0.16 & 0.11 \\
\hline & k2 & 0.10 & 0.08 & 0.07 & 35.15 & 15.56 & 36.69 & 0.03 & -0.01 & - & 0.74 & -0.01 & 0.01 \\
\hline & $\mathbf{m}$ & 0.44 & 0.47 & 0.48 & 0.13 & 0.26 & 0.17 & 0.56 & 0.56 & - & 0.51 & 0.64 & 0.71 \\
\hline \multirow{4}{*}{18.} & k1 & 0.43 & 0.28 & 0.30 & -37.46 & -16.63 & -38.63 & 0.16 & 0.17 & 0.33 & -0.74 & 0.25 & -0.21 \\
\hline & k2 & 0.07 & 0.08 & 0.07 & 35.07 & 15.54 & 36.48 & 0.03 & -0.01 & 0.02 & 0.74 & 0.09 & 0.03 \\
\hline & $\mathbf{m}$ & 0.47 & 0.47 & 0.48 & 0.13 & 0.26 & 0.17 & 0.56 & 0.56 & 0.16 & 0.51 & 0.14 & 0.65 \\
\hline & Tlag & 0.00 & 0.00 & 0.00 & 0.00 & 0.00 & 0.00 & 0.00 & 0.00 & 0.00 & 0.00 & 2.00 & -22.56 \\
\hline \multirow{2}{*}{19.} & k1 & 0.45 & 0.31 & 0.31 & 2.10 & 1.93 & 3.77 & 0.13 & 0.18 & 0.27 & -0.82 & 0.21 & 0.03 \\
\hline & k2 & 0.04 & 0.05 & 0.06 & 0.48 & 1.45 & 0.98 & 0.06 & -0.01 & -0.03 & 0.78 & -0.02 & 0.07 \\
\hline \multirow{3}{*}{20.} & k1 & 0.45 & 0.31 & 0.31 & 3.69 & 4.48 & 6.50 & 0.13 & 0.18 & 0.27 & -0.82 & 0.25 & -0.47 \\
\hline & k2 & 0.04 & 0.05 & 0.06 & 0.20 & 1.04 & 0.52 & 0.06 & -0.01 & -0.03 & 0.78 & -0.03 & 0.12 \\
\hline & Tlag & 0.00 & 0.00 & 0.00 & 1.87 & 1.74 & 1.76 & 0.00 & 0.00 & 0.00 & 0.00 & 1.59 & -17.20 \\
\hline \multirow{3}{*}{23.} & $\alpha$ & 229.18 & 326.99 & 320.35 & 30.11 & 31.21 & 19.99 & 748.20 & 499.68 & 284.95 & 260.19 & 292.99 & $1.1 \cdot 10^{4}$ \\
\hline & $\beta$ & 0.64 & 0.70 & 0.70 & 0.65 & 0.94 & 0.77 & 0.87 & 0.37 & 0.18 & 1.19 & 0.19 & 1.57 \\
\hline & $\mathbf{T i}$ & 0.00 & -0.03 & -0.02 & 1.77 & 1.15 & 1.42 & -0.47 & 0.33 & 0.00 & 0.80 & 1.99 & -7.51 \\
\hline \multirow{2}{*}{24.} & $\alpha$ & 229.17 & 324.53 & 318.72 & 49.84 & \begin{tabular}{|l|}
45.99 \\
\end{tabular} & 31.11 & 653.45 & 525.85 & 284.93 & 342.54 & \begin{tabular}{|l|l|}
458.71 \\
\end{tabular} & $1.1 \cdot 10^{3}$ \\
\hline & $\beta$ & 0.64 & 0.70 & 0.70 & 0.79 & 1.04 & 0.90 & 0.83 & 0.38 & 0.18 & 1.26 & 0.34 & 0.98 \\
\hline \multirow{3}{*}{25.} & $\alpha$ & $4.0 \cdot 10^{6}$ & $1.9 \cdot 10^{6}$ & $4.2 \cdot 10^{5}$ & 43.65 & \begin{tabular}{|l|}
43.49 \\
\end{tabular} & 36.28 & $5.0 \cdot 10^{6}$ & 5.37 & $5.3 \cdot 10^{6}$ & 165.46 & 5.06 & $6.2 \cdot 10^{6}$ \\
\hline & $\beta$ & 0.63 & 0.70 & 0.70 & 1.53 & 1.27 & 1.38 & 0.83 & 0.59 & 0.18 & 1.55 & 0.95 & 0.99 \\
\hline & Fmax & $1.7 \cdot 10^{6}$ & $5.9 \cdot 10^{5}$ & $1.3 \cdot 10^{5}$ & 24.08 & 63.14 & 49.67 & $7.7 \cdot 10^{5}$ & 0.92 & $1.8 \cdot 10^{4}$ & 27.21 & 0.63 & $5.2 \cdot 10^{5}$ \\
\hline \multirow{4}{*}{26.} & $\alpha$ & 229.17 & 324.53 & 318.72 & 49.84 & \begin{tabular}{|l|}
45.99 \\
\end{tabular} & 31.11 & 653.45 & 525.85 & 284.93 & 342.54 & 458.71 & $1.1 \cdot 10^{3}$ \\
\hline & $\beta$ & 0.64 & 0.70 & 0.70 & 0.79 & 1.04 & 0.90 & 0.83 & 0.38 & 0.18 & 1.26 & 0.34 & 0.98 \\
\hline & $\mathbf{T i}$ & 0.00 & -0.03 & -0.03 & 0.68 & 0.48 & -0.89 & -0.45 & 0.00 & 0.01 & -1.03 & \begin{tabular}{|l|}
1.99 \\
\end{tabular} & -0.50 \\
\hline & Fmax & $6.1 \cdot 10^{5}$ & $8.6 \cdot 10^{4}$ & $4.4 \cdot 10^{5}$ & 24.59 & 67.23 & 48.36 & $2.1 \cdot 10^{2}$ & 0.92 & 6.34 & 24.84 & $3.9 \cdot 10^{4}$ & $4 \cdot 10^{5}$ \\
\hline
\end{tabular}




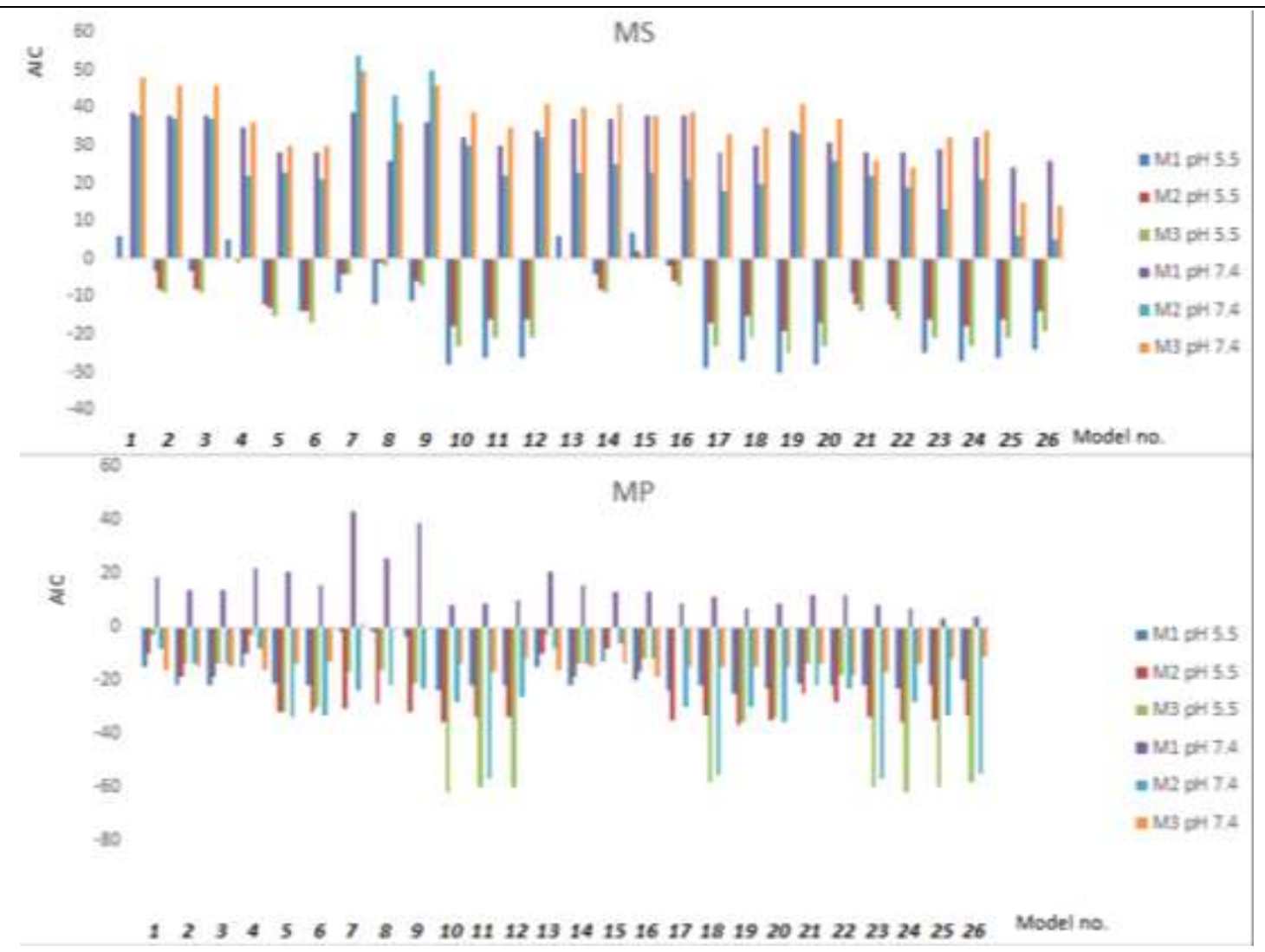

Figure 2.

The Akaike indexes of the formulations (MS synthetic membrane, MP pig ear skin)

The AIC indexes for the 26 mathematical models are shown on Figure 2. The index estimates the relative amount of information lost by a given mathematical model; the best fit model is with minimum value.
Values of AIC varied in the range $[49 \div-62]$. Minimal values for the three different formulations at both pH appear at the Korsmeyer-Peppas, Peppas-Sahlin and Weibull models.

Table V

Skin permeation values and lag times of the formulations

\begin{tabular}{|c|c|c|c|c|c|c|}
\hline \multicolumn{5}{|c|}{$\mathbf{J}\left(\mu \mathrm{g} /\left(\mathbf{c m}^{2} \mathbf{h}\right) \pm \mathbf{D S}\right.$} & \multicolumn{2}{c|}{$\mathbf{T}_{\text {lag }}(\mathbf{h})$} \\
\hline M & \multicolumn{2}{|c|}{ MS } & \multicolumn{2}{c|}{ MP } & MS & MP \\
\hline pH & $\mathbf{5 . 5}$ & $\mathbf{7 . 4}$ & $\mathbf{5 . 5}$ & $\mathbf{7 . 4}$ & $\mathbf{7 . 4}$ & $\mathbf{7 . 4}$ \\
\hline M1 & $1.95 \pm 0.017$ & $22.11 \pm 0.359$ & $1.18 \pm 0.012$ & $11.15 \pm 0.874$ & 2.006 & 3.469 \\
\hline M2 & $1.44 \pm 0.022$ & $31.79 \pm 0.566$ & $0.26 \pm 0.020$ & $0.10 \pm 0.008$ & 0.843 & - \\
\hline M3 & $1.43 \pm 0.014$ & $32.20 \pm 0.530$ & $0.18 \pm 0.025$ & $0.95 \pm 0.019$ & 0.359 & - \\
\hline
\end{tabular}

The matrix forming polymer by its properties influences the liberation of meloxicam. In our case, HPMC can be characterized by high swellability, ensuring a gradual liberation. In contact with biologic fluids the polymer chains of HPMC relaxes and their volume increases, followed by drug diffusion out of the system [22]. Diffusion from this kind of system can be described by Fick's law. The rate of polymer swelling and dissolution as well as the corresponding rate of drug release were found to increase with either higher levels of drug loading or lower viscosity grades of HPMC [19, 21]. Through MP formulation M1 (matrix based on $\mathrm{HPMC}_{\mathrm{E} 5}$ ) showed the highest liberated MX values after 30 hours $2.55 \%$ at $\mathrm{pH} 5.5$, and $18.71 \%$ at $\mathrm{pH}$ 7.4. Released $\mathrm{MX}$ from M2 (matrix based on $1 \% \mathrm{HPMC}_{15000}$ ) at both $\mathrm{pH}$ and MP membrane was lower than 1\%. M3 formulation (matrix based on $1.5 \% \mathrm{HPMC}_{15000}$ ) present also under $1 \%$ liberated $\mathrm{MX}$ at $\mathrm{pH} 5.5$, and $2.57 \%$ at $\mathrm{pH} 7.4$. We can assume that adding high viscosity polymer such as $\mathrm{HPMC}_{15000}$ to the formulations M2 and M3 decreased the released MX amount through MP after 30 hours, at both $\mathrm{pH}$. Through MS at $\mathrm{pH} 5.5$ the released MX amounts are 3.18\%, 3.75\% and 3.31\% for formulation M1, M2 and M3 after 30 hours. At $\mathrm{pH} 7.4$ the highest concentration of MX released was observed for M2 formulation (52.1\%).

The Korsmeyer Peppas model includes the Korsmeyer Peppas constant, characterizing the dosage form and $n$ is the release exponent. This exponent offers information about drug-release mechanism [6]. If $\mathrm{n}$ is below 0.5 the drug diffuses through and is released from polymeric film with a quasi-Fickian diffusion 
mechanism. If $\mathrm{n}$ is above 0.5 , a non-Fickian drug diffusion takes place. When $\mathrm{n}$ is higher than 1.0, a Case II or zero-order release kinetics may describe the process. In case of TTS the release occurs in a one-dimensional way, the system being thin. In our case $\mathrm{n}$ is above 0.5 for all formulations at both $\mathrm{pH}$ through the synthetic membrane. Values vary for the porcine ear skin membrane, but transdermal absorption is a multifactorial multi-step process, affected by a number of factors including the animal source and type of skin as well as skin pre-treatment [4].

Weibull model is an empiric model that is not based on any kinetic fundament. It can only describe, but do not adequately characterize, the drug dissolution kinetic properties. The main disadvantage of the model is represented by the absence of a parameter related with the intrinsic drug dissolution rate.

Permeability through biological membranes is facilitated by the $\mathrm{pH}$ dependent lipophilic character of meloxicam, belonging to the class II drugs in the Biopharmaceutics Classification System. The greatest MX flux variation is from 0.1 to $31.8 \mu \mathrm{g} /\left(\mathrm{cm}^{2} \mathrm{~h}\right)$, for M2 at $\mathrm{pH} 7.4 \mathrm{MS}$ and MP membrane, respectively. The flux is higher in the case of $\mathrm{HPMC}_{\mathrm{E} 5}$ containing matrix as compared to those containing $\mathrm{HPMC}_{15000}$ probably due to the viscosity differences of the two types of polymer. Comparing flux values through MS membrane, a 22 fold increase may be observed for formulation M2 and $\mathrm{M} 3$ from $\mathrm{pH} 5.5$ to $\mathrm{pH}$ 7.4.

\section{Conclusions}

To characterise the liberation of meloxicam from polymer-based films intended for TTS, mathematical modelling was applied. Discrimination of the models was realized by analysing the AIC value, considering the smallest value to be the best fit for the model. Liberation of meloxicam is influenced by formulation variables as well as test parameters.

Due to the fact that drug release in TTS cases occurs in a one-dimensional way following the KorsmeyerPeppas indications, this equation represents a good choice in the study of these pharmaceutical systems.

\section{Acknowledgement}

This work was supported by the University of Medicine and Pharmacy of Târgu Mureș Research Grant number 275/6 /11.01.2017.

\section{Conflict of interest}

The authors declare no conflict of interest.

\section{References}

1. Antonoaea P, Ciurba A, Todoran N, Vlad RA, Muntean DL, Validation of high performance liquid cromatography methods for quantification of meloxicam and tenoxicam from transdermal therapeutic systems. Acta Medica Marisinesis, 2017; 63(4): 178-182.

2. Antonoaea P, Sylvester B, Tomuţă I, Ciurba A, Rédai E, Todoran N, Muntean DL, Direct quantification of meloxicam from transdermal therapeutic systems by NIR spectroscopy. Farmacia, 2017; 65(2): 230-236.

3. Barner A, Review of Clinical Trials and Benefit/Risk Ratio of Meloxicam. Scand J Rheumatol., 1996; 25(sup102): 29-37.

4. Bartosova L, Bajgar J, Transdermal Drug Delivery in Vitro Using Diffusion Cells. Curr Med Chem., 2012; 19(27): 4671-4677.

5. Bassleer C, Magotteaux J, Geenen V, Malaise M, Effects of meloxicam compared to acetylsalicylic acid in human articular chondrocytes. Pharmacology, 1997; 54(1): 49-56.

6. Bîrsan M, Cristofor AC, Antonoaea P, Todoran N, Bibire N, Panainte AD, Vlad RA, Grigore M, Ciurba A. Evaluation of miconazole nitrate permeability through biological membrane from dermal systems. Farmacia, 2020; 68(1): 111-115.

7. Ciurba A, Todoran N, Taurean A, Antonoaea P, Hancu G, Moisei A, Sipos E, Kinetic analysis of in vitro drug release from valproic acid and sodium valproate suppositories. Farmacia, 2014; 62(6): 1143-1156.

8. Costa P, Sousa Lobo JM, Evaluation of mathematical models describing drug release from estradiol transdermal systems. Drug Dev Ind Pharm., 2003; 29(1): 89-97.

9. Costa P, Sousa Lobo JM, Modeling and comparison of dissolution profiles. Eur J Pharm Sci., 2001; 13(2): 123-133.

10. Das B, Nayak AK, Nanda U, Topical gels of lidocaine $\mathrm{HCl}$ using cashew gum and Carbopol 940: Preparation and in vitro skin permeation. Int J Biol Macromol., 2013; 62: 514-517.

11. Dash S, Murthy PN, Nath L, Chowdhury P, Kinetic modeling on drug release from controlled drug delivery systems. Acta Pol Pharm., 2010; 67(3): 217-223.

12. Duangjit $S$, Opanasopit $P$, Rojanarata $T$, Ngawhirunpat $T$, Evaluation of Meloxicam-Loaded Cationic Transfersomes as Transdermal Drug Delivery Carriers. AAPS Pharm Sci Tech., 2013; 14(1): 133-140.

13. Engelhardt G, Pharmacology of Meloxicam, A New Non-Steroidal Anti-Inflammatory Drug with an Improved Safety Profile Through Preferential Inhibition of COX-2. Rheumatology, 1996; 35(suppl_1): 4-12.

14. Farahmand S, Maibach HI, Estimating skin permeability from physicochemical characteristics of drugs: A comparison between conventional models and an in vivo-based approach. Int J Pharm., 2009; 375(1): 41-47.

15. Hadgraft JGR, Feasibility assessment in topical and transdermal delivery: mathematical models and in vitro studies. Transdermal drug delivery, 2 ed. New York: Marcel Dekker, 2003; 1-23.

16. Khurana S, Jain NK, Bedi PMS, Nanoemulsion based gel for transdermal delivery of meloxicam: Physicochemical, mechanistic investigation. Life Sci., 2013; 92(6): 383-392.

17. Ngawhirunpat $T$, Opanasopit $P$, Rojanarata $T$, Akkaramongkolporn P, Ruktanonchai U, Supaphol $\mathrm{P}$, Development of meloxicam-loaded electrospun polyvinyl alcohol mats as a transdermal therapeutic agent. Pharm Dev Technol., 2009; 14(1): 73-82. 
18. Olariu I, Coneac G, Hîrjău M, Popoiu C, Muţ AM, Vlaia V, Sevastre AS, Lupuliasa D, Vlaia L, Evaluation of the barrier potential of some synthetic membranes in testing the in vitro tenoxicam release from hydrogels, using the experimental model with Franz diffusion cells. Farmacia, 2019; 67(1): 73-80.

19. Pham AT, Lee PI, Probing the Mechanisms of Drug Release from Hydroxypropylmethyl Cellulose Matrices. Pharm Res., 1994; 11(10): 1379-1384.

20. Roaa AN, Ahmed AH, Preparation and Evaluation of Meloxicam Microsponges as transdermal delivery system. Iraqi J Pharm Sci., 2014; 23(2): 62-74.

21. Siepmann J, Kranz H, Bodmeier R, Peppas NA, HPMC-matrices for controlled drug delivery: A new model combining diffusion, swelling, and dissolution mechanisms and predicting the release kinetics. Pharm Res., 1999; 16(11): 1748-1756.
22. Siepmann J, Peppas NA, Modeling of drug release from delivery systems based on hydroxypropyl methylcellulose (HPMC). Adv Drug Deliv Rev., 2012; 64: $163-174$

23. Somasundaram Jayaprakash, Ramkanth $S$, Anitha $P$, Alagusundaram M, Saleem MTS, Chetty MC, Design and evaluation of monolithic drug-in-adhesive transdermal patches of meloxicam. Malays J Pharm Sci., 2010; 8(2): 25-43.

24. Yuan Y, Li SM, Mo FK, Zhong DF, Investigation of microemulsion system for transdermal delivery of meloxicam. Int J Pharm., 2006; 321(1): 117-121.

25. Zhang Y, Huo M, Zhou J, Zou A, Li W, Yao C, DDSolver: An Add-In Program for Modeling and Comparison of Drug Dissolution Profiles. AAPS J., 2010; 12(3): 263-271. 